\title{
PENERAPAN ETIKA BISNIS ISLAM PADA WAROENG STEAK AND SHAKE MEDAN
}

\author{
Rizka Ar Rahmah \\ STAIN Mandailing Natal \\ rizkaarrahmah@stain-madina.ac.id
}

\begin{abstract}
This research aims to determine the concept of business ethics which is implemented in Waroeng Steak and Shake, SM Raja Medan Branch. Waroeng Steak and Shake is a culinary business that underlies every business activity according to the rules of the Al-Quran and Sunnah. This study used a qualitative approach with data validation techniques by extracting information from related respondents and by making direct observations for data verification. Research results can be known and felt by researchers about the existence of different religious nuances compared to the culinary business in general at Waroeng Steak has implemented Islamic business ethics properly using the concepts of Shiddiq, tabligh, amanah and fathanah, which guarantees good and halal ingredients and honesty in transactions, the delivery of da'wah through business, and honesty in financial reports. However, this shop needs to have an increase in service and spiritual intelligence. So it is suggested to make a program Smile, Greetings and Greetings in improving services and prayer activities in turn to improve spiritual intelligence.

Keywords: business, culinary, ethics, Islam, management
\end{abstract}

\begin{abstract}
Abstrak
Penelitian ini bertujuan untuk mengetahui konsep etika bisnis yang dilaksanakan di Waroeng Steak and Shake Cabang SM Raja Medan. Waroeng Steak and Shake ini adalah salah satu bisnis kuliner yang melandasi setiap kegiatan bisnisnya sesuai dengan aturan Al-quran dan Sunnah. Penelitian ini menggunakan pendekatan kualitatif dengan teknik validasi data dilakukan dengan cara menggali informasi dari responden yang terkait dan dengan melakukan observasi langsung untuk verifikasi data. Hasil penelitian dapat diketahui dan dirasakan oleh peneliti akan adanya nuansa keagamaan yang berbeda dibandingkan dengan bisnis kuliner pada umumnya di Waroeng Steak sudah menerapkan etika bisnis Islam dengan baik menggunakan konsep Shiddiq, tabligh, amanah dan fathanah, yakni menjamin bahan baik dan halal serta kejujuran dalam bertransaksi, adanya penyampaian dakwah melalui bisnis, dan jujur dalam laporan keuangan. Namun, warung ini perlu memiliki peningkatan pelayanan dan kecerdasan spiritual. Sehingga disaranlan untuk membuat program Senyum, Salam dan Sapa dalam memperbaiki pelayanan dan kegiatan shalat berjamaah secara bergantian untuk memperbaiki kecerdasan spiritual.

Kata Kunci: bisnis, kuliner, etika, Islam, manajemen
\end{abstract}

\section{Pendahuluan}

Bisnis merupakan sesuatu yang sangat penting dalam kehidupan manusia. Tidak heran jika Islam yang bersumber pada Alquran dan Sunnah memberi tuntunan dalam bidang usaha. Bisnis selama ini, dikesankan sebagai usaha mencari keuntungan 
sebanyak-banyaknya, bahkan harus ditempuh dengan cara kotor dan tidak etis. Islam tidak membiarkan begitu saja seseorang bekerja sesuka hati untuk mencapai keinginannya dengan menghalalkan segala cara seperti melakukan penipuan, kecurangan, sumpah palsu, riba, menyuap dan perbuatan batil lainnya. Tetapi dalam Islam diberikan suatu batasan atau garis pemisah antara yang boleh dan yang tidak boleh, yang benar dan salah serta yang halal dan yang haram. Allah SWT telah menetapkan batas-batas tertentu terhadap perilaku manusia sehingga menguntungkan satu individu tanpa mengorbankan hak-hak individu lainnya. Batasan atau garis pemisah inilah yang dikenal dengan istilah etika.

Berbicara masalah etika memang tidak akan pernah menemui titik temu, hal ini di sebabkan adanya faktor relativisme yang berbeda-beda antar manusia. Bagi seseorang mungkin etika tidak terlalu penting, tetapi bagi yang lain bisa jadi etika adalah hal yang utama dibanding dengan aspek kehidupan yang lain.

Namun ketika etika dikaitkan dengan ekonomi, tentunya semua orang sudah mengetahui bahwa peranan etika sangat-sangat menentukan hasil penjualan maupun jasa. Etika dalam ekonomi tidak hanya berbicara pada tataran perilaku penjual tapi juga menyangkut kredibilitas dari produk atau jasa yang ditawarkan. Dan secara tidak langsung etika penjualan akan berimbas pada hasil daripada penjualan itu sendiri.

Etika bisnis Islam bertujuan mengajarkan manusia untuk menjalin kerjasama, tolong menolong, dan menjauhkan diri dari sikap dengki dan dendam serta hal-hal yang tidak sesuai dengan syariah. ${ }^{1}$ Etika bisnis dalam Islam juga berfungsi sebagai controlling (pengatur) terhadap aktifitas ekonomi pedagang, karena secara filosofi etika mendasarkan diri pada nalar ilmu dan agama untuk menilai. Landasan penilaian ini dalam praktek kehidupan di masyarakat sering kita temukan bahwa secara agama terdapat nilai mengenai hal-hal baik, buruk atau jahat, seperti pihak yang mendzalimi dan terdzalimi. ${ }^{2}$ Dengan begitu maka setiap individu yang melakukan kegiatan ekonomi baik seorang pebisnis atau yang menjalankan aktivitas ekonomi maka harus memiliki pengetahuan akan etika bisnis Islam agar terhindar dari tindakan bisnis yang dilarang oleh Allah SWT.

Pelaksanaan etika bisnis Islam yang efektif, mengarah kepada pola pembagunan akhlak mulia perilaku pengusaha atau sumber daya manusia serta stakeholders, 
dengan melaksanakan prinsip-prinsip dan standar etika bisnis, meliputi: Kejujuran (honesty), tidak curang dan tidak berbohong, integritas, memegang prinsip, tulus hati dan penuh keyakinan, memelihara janji, penuh komitmen dan patut dipercaya. kesetiaan, melaksanakan kewajiban menunaikan tugas, keadilan, berbudi luhur dan komitmen keadilan, suka membantu orang lain dan kerjasama, hormat kepada orang lain, menghormati kebebasan dan hak menentukan nasib, bertanggungjawab, mentaati hukum, kesadaran sosial dan demokrasi.

Munculnya wacana pemikiran etika bisnis, didorong oleh realitas bisnis yang mengabaikan nilai-nilai moral atau akhlak. Bagi beberapa pihak, bisnis adalah aktivitas ekonomi manusia yang bertujuan mencari laba semata-mata. ${ }^{3}$ Pada dasarnya etika (nilai-nilai dasar) dalam bisnis berfungsi untuk menolong pebisnis (dalam hal ini pedagang) untuk memecahkan problem-problem (moral) dalam praktek bisnis mereka. Oleh karena itu, dalam rangka mengembangkan sistem ekonomi Islam khususnya dalam upaya revitalisasi perdagangan Islam sebagai jawaban bagi kegagalan sistem ekonomi baik kapitalisme maupun sosialisme, menggali nilai-nilai dasar Islam tentang aturan perdagangan dari Alquran maupun as-Sunnah, merupakan suatu hal yang niscaya untuk dilakukan.

\section{Kajian Teori}

Etika pada umumnya didefinisikan sebagai suatu usaha yang sistematis dengan menggunakan rasio untuk menafsirkan pengalaman moral individual dan sosial sehingga, dapat menetapkan aturan untuk mengendalikan perilaku manusia serta nilai-nilai yang berbobot untuk dapat dijadikan sasaran dalam hidup. ${ }^{4}$ Menurut Suparman Syukur dalam bukunya yang berjudul Etika Religi menjelaskan bahwa istilah etika juga sering digunakan dalam tiga perbedaan yang saling terkait, pertama merupakan pola umum atau jalan hidup, kedua seperangkat aturan atau kode moral, dan ketiga penyelidikan tentang jalan hidup dan aturan-aturan perilaku. ${ }^{5}$

Kata Bisnis dalam bahasa indonesia diserap dari kata business dari bahasa inggris yang berarti kesibukan. Kesibukan secara khusus berhubungan dengan orentasi profit atau keuntungan. ${ }^{6}$ Secara etimologi, bisnis berarti keadaan dimana seseorang atau sekelompok orang sibuk melakukan pekerjaan yang menghasilkan keuntungan. Kata bisnis sendiri dapat merujuk pada badan usaha, yaitu kesatuan 
yuridis (hukum), teknis, dan ekonomis yang bertujuan mencari laba atau keuntungan. ${ }^{7}$

Bisnis dalam arti luas adalah istilah umum yang menggambarkan semua aktivitas dan institusi yang memproduksi barang dan jasa dalam kehidupan sehari hari. Bisnis merupakan suatu organisasi yang menyediakan barang dan jasa yang bertujuan untuk mendapatkan keuntungan. ${ }^{8}$

Etika bisnis dapat berarti pemikiran atau refleksi tentang moralitas dalam ekonomi dan bisnis. Moralitas disini berarti aspek baik atau buruk, terpuji atau tercela, benar atau salah dari prilaku manusia. Kemudian dalam kajian etika bisnis islam susunan adjective diatas ditambah dengan halal dan haram.

Jadi kesimpulan deskripsi mengenai etika bisnis Islam merupakan suatu proses dan upaya untuk mengetahui hal-hal yang benar dan yang salah yang berkenaan dengan produk, pelayanan perusahaan dengan pihak yang berkepentingan dengan tuntutan perusahaan yang selanjutnya dijadikan sebagai kerangka praktis yang secara fungsional akan membentuk suatu kesadaran beragama dalam melakukan setiap kegiatan ekonomi. ${ }^{9}$

Etika bisnis dalam Islam adalah sejumlah perilaku etika bisnis (akhlaq alislamiyah) yang dibungkus dengan nilai-nilai syariah yang mengedepankan halal dan haram. Jadi perilaku yang etis itu ialah perilaku yang mengikuti perintah Allah dan menjauhi larangnya. Dalam islam etika bisnis ini sudah banyak dibahas dalam berbagai literatur dan sumber utamanya adalah Alquran dan sunnaturrasul. Pelakupelaku bisnis diharapkan bertindak secara etis dalam berbagai aktivitasnya. Kepercayaan, keadilan dan kejujuran adalah elemen pokok dalam mencapai suksesnya suatu bisnis dikemudian hari.

\section{Prinsip-Prinsip Etika Bisnis Islam}

Rasulullah SAW memiliki sifat - sifat ke-Rasul-an yang menjadi dasar etika bisnis ala Rasulullah yaitu shiddiq, amanah, tabligh dan fathanah. Kejujuran (asshiddiq) dan kepercayaan (al-amin) menjadi prinsip utama Rasulullah SAW dalam berbisnis, selain itu beliau juga terhitung sebagai orang yang cerdas (fathanah) dengan pemikiran yang visioner, kreatif dan inovatif, serta pintar mempromosikan 
diri dan bisnisnya (tabligh) atau dalam istilah ekonomi dikenal dengan marketing, semua itu menyatu dalam diri Rasulullah SAW. ${ }^{10}$

\section{1) Shiddiq}

Shiddiq artinya benar. Bukan hanya perkataannya yang benar, tapi juga perbuatannya juga benar. Sejalan dengan ucapannya. ${ }^{11}$

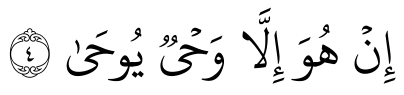

Artinya: Ucapannya itu tiada lain hanyalah wahyu yang diwahyukan (kepadanya). ${ }^{12}$

Seorang pemimpin senantiasa berprilaku benar dan jujur dalam sepanjang kepemimpinannya, dan seorang pemasar haruslah sifat shiddiq haruslah menjiwai setiap prilakunya dalam melakukan pemasaran, dalam berhubungan dengan pelanggan, dalam bertransaksi dengan nasabah, dan dalam menjalin kerjasama dan perjanjian dengan mitra bisnisnya.

2) Amanah

Amanah artinya benar-benar bisa dipercaya. Jika satu urusan diserahkan kepadanya, niscaya orang percaya bahwa urusan itu akan dilaksanakan dengan sebaik-baiknya. Oleh karena itulah Rasulullah Saw dijuluki oleh penduduk Mekkah dengan gelar "Al Amin" yang artinya terpercaya jauh sebelum beliau diangkat jadi Nabi. Apa pun yang beliau ucapkan, penduduk Mekkah mempercayainya karena beliau bukanlah orang yang pembohong. Sebagaimana telah diterangkan dalam ayat berikut ini: (QS. Al-A'raaf : 68)

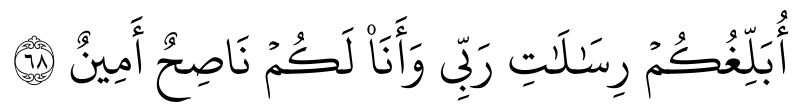

Artinya: Aku menyampaikan amanat-amanat Tuhanku kepadamu dan aku hanyalah pemberi nasehat yang terpercaya bagimu. ${ }^{13}$

Dapat dipercaya, bertanggung jawab, juga bermakna keinginan untuk memenuhi sesuatu sesui dengan ketentuan. Menyelaraskan nilai yang terkait dengan kejujuran dan melengkapinya.

3) Tabligh 
Tabligh artinya menyampaikan. Segala firman Allah yang ditujukan oleh manusia, disampaikan oleh Nabi.Tidak ada yang disembunyikan meski itu menyinggung Nabi.

"Supaya Dia mengetahui, bahwa Sesungguhnya Rasul-rasul itu telah menyampaikan risalah-risalah Tuhannya, sedang (sebenarnya) ilmu-Nya meliputi apa yang ada pada mereka, dan Dia menghitung segala sesuatu satu persatu”. (QS. Al Jin :28)
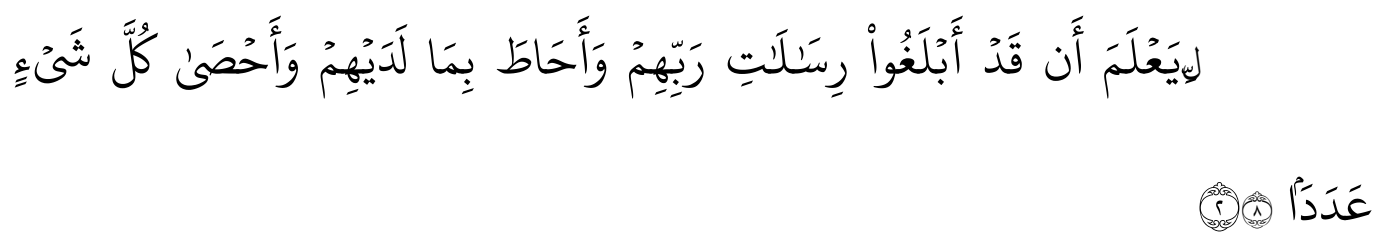

Artinya: Supaya Dia mengetahui, bahwa sesungguhnya rasul-rasul itu telah menyampaikan risalah-risalah Tuhannya, sedang (sebenarnya) ilmu-Nya meliputi apa yang ada pada mereka, dan Dia menghitung segala sesuatu satu persatu. ${ }^{14}$

4) Fathanah

Fathanah artinya cerdas. Mustahil Nabi itu bodoh. Dalam menyampaikan 6 ribu lebih ayat Al Qur'an kemudian menjelaskannya dalam puluhan ribu hadits membutuhkan kecerdasan yang luar biasa. Nabi harus mampu menjelaskan firmanirman Allah kepada kaumnya sehingga mereka mau masuk ke dalam Islam. Nabi juga harus mampu berdebat dengan orang-orang kafir dengan cara yang sebaik-baiknya. Apalagi Nabi mampu mengatur ummatnya sehingga dari bangsa Arab yang bodoh dan terpecah-belah serta saling perang antar suku, menjadi satu bangsa yang berbudaya dan berpengetahuan. Dan dapat diartikan sebagai seorang pemasar harus cerdik dan bijaksana, dalam kata lain adalah pemasar harus mengerti, memahami, menghayati secara mendalam segala hal yang menjadi tugas dan kewajibannya.

\section{Spiritual Company}

Spiritual company adalah perusahaan yang menggunakan nilai-nilai spiritualitas sebagai landasan misi dan visinya. Nilai-nilai spiritual yang dijadikan landasan dasar misi dan visi perusahaan bersifat universal. Kalaupun pada pelaksanaannya sulit dipisahkan antara praktik spiritualitas dan religiositas atau bahkan kedua nilai tersebut menyatu hal itu bukan berarti perusahaan melakukan 
keberpihakan pada suatu agama tertentu. Spiritual company akan selalu melakukan proses operasional perusahaan berdasarkan landasan nilai-nilai luhur yang tidak saja memikirkan dampaknya dalam jangka pendek tetapi dimensi yang digunakan adalah dimensi jangka panjang. Dimensi jangka panjang yang dimaksud adalah pertanggungjawaban segala yang dilakukan di hadapan the ultimate stakeholder (Allah).

Nilai-nilai spiritualitas dalam perusahaan akan menempatkan karyawan pada posisi yang tepat sebagai manusia. Demikian pula karyawan mampu memaknai kerja sebagai ibadah dan perwujudan pertanggungjawaban kepada the ultimate stakeholder (Allah). Hal ini akan berdampak pada komitmen organisasi yang tinggi.

\section{Metode Penelitian}

Penelitian ini menggunakan perspektif pendekatan kualitatif secara deskriptif dengan menggunakan studi fenomenologi. Menurut Denzin dan Lincoln menyatakan bahwa penelitian kualitatif adalah penelitian yang menggunakan latar alamiah, dengan maksud menafsirkan fenomena yang terjadi dan dilakukan dengan jalan melibatkan berbagai metode yang ada. ${ }^{15}$ Metode deskriptif umumnya memiliki 2 ciri khas utama: ${ }^{16}$

1) Memusatkan diri pada masalah-masalah yang ada sekarang

2) Data yang dikumpulkan pertama kali disusun, dijelaskan kemudian dianalisa karena itu metode deskriptif sering disebut metode analisa.

Melalui metode penelitian deskriptif, metode ini berusaha mendeskripsikan atau melukiskan secara terperinci atau mendalam bagaimana etika dan manajemen bisnis Islam di Waroeng Steak and Shake Cabang SM. Raja Medan. Dengan pemilihan rancangan deskriptif kualitatif, maka penulis akan melakukan pendekatan terhadap obyek penelitian dengan menggali informasi sesuai dengan persepsi penulis dan responden yang dapat berkembang sesuai dengan interaksi yang terjadi dalam proses wawancara. Penulis senantiasa menginterpretasikan makna yang tersurat dan tersirat dari penjelasan yang diberikan informan, hasil observasi lapangan serta catatan pribadi. Adapun teknik pengumpuan data yang digunakan dengan teknik simak, observasi, wawancara semi berstruktur dan dokumentasi. Responden pada penelitian ini adalah supervisor dan karyawan outlet. 
Rizka Ar Rahmah: Penerapan Etika Bisnis Islam Pada Waroeng Steak | 253

\section{Hasil Dan Pembahasan}

Dalam etika bisnis Islam, ada 4 prinsip sifat dasar Rasulullah saw yang harus dimiliki, yaitu shiddiq (kejujuran), amanah (bertanggungjawab dan dapat dipercaya), tabligh (menyampaikan), dan fathanah (cerdas).

\section{1) Shiddiq (kejujuran)}

Sikap jujur yang diterapkan oleh Waroeng Steak and Shake Cabang SM Raja Medan dalam menjalankan bisnis kulinernya meliputi hal-hal berikut:

a) Menjamin bahan baik dan halal.

Salah satu hal yang perlu diperhatikan mengenai kehalalan menu steak adalah bahan utamanya yang berupa daging sapi atau daging ayam. Haruslah dipastikan bahwa daging tersebut diproses dengan cara penyembelihan halal. Selain daging, campuran bumbu, alat, cara memasak juga tak boleh luput dari pengawasan, karena hal-hal tersebut juga menentukan kehalalan masakan. Waroeng Steak and Shake menjamin bahwa daging yang mereka gunakan adalah daging dengan kualitas bagus, juga dijamin kehalalannya karena pihak supplier daging yang mereka ajak bekerja sama adalah supplier yang memiliki pemahaman agama yang baik begitu juga dengan penerapannya. Seperti wawancara yang dilakukan dengan karyawan berinisial Yusuf ${ }^{17}$ :

Disini kami menjamin bahwa daging yang kami gunakan adalah daging yang disembelih dengan menyebut dengan nama Allah. Kami juga memilih supplier yang kami percaya beragama Islam yang baik. Selain daging, sayuran yang kami pakai juga sayuran yang fresh. Penyuplai sayuran langsung mengantarkan sayuran setiap harinya ke outlet. Kami juga bisa lebih meyakinkan konsumen dengan mendaftarkan produk kami di LPPOM MUI dan alhamdulillah kami sudah bersertifikat Halal MUI.

Sedangkan menurut $\mathrm{E}^{18}$ :

Salah satu hal penting yang harus diperhatikan yaitu kualitas daging. Daging yang akan digunakan sebagai bahan baku steak harus memiliki kualitas yang bagus untuk menghasilkan steak yang berkualitas. Wajib diperhatikan juga tentang cara memasak yang benar. Juga cara membuat saus steak yang sedap 
untuk menarik minat pengunjung. Serta bagaimana cara penyajian yang sesuai untuk hidangan steak.

Q.S Al-Mu'minun : 51

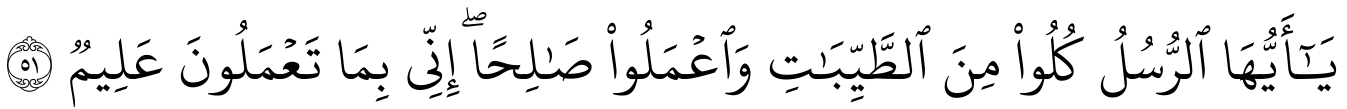

Artinya: Hai rasul-rasul, makanlah dari makanan yang baik-baik, dan kerjakanlah amal yang saleh. Sesungguhnya Aku Maha Mengetahui apa yang kamu kerjakan.

Ayat ini merupakan perintah dari Allah kepada para rasul-Nya untuk memakan makanan yang baik-baik, yakni rezeki yang baik lagi halal, dan bersyukur kepada Allah dengan beramal saleh, di mana dengannya hati dan badannya menjadi baik, demikian pula dunia dan akhiratnya. Allah swt juga memberitahukan, bahwa Dia mengetahui amal yang mereka kerjakan. Oleh karena itu, setiap amalan dan pekerjaan yang mereka kerjakan, maka Allah mengetahuinya serta akan memberikan balasan terhadapnya secara sempurna.

Berikut ini wawancara dengan salah seorang konsumen bernama Putri ${ }^{19}$ :

Saya sudah berkali-kali datang ke Waroeng Stean and Shake yang di cabang SM Raja ini, alhamdulillah pesanan saya selalu bagus. Dagingnya enggak keras dan enggak ada bau yang aneh. Soalnya kalau dagingnya kurang segar pasti ada aroma yang kurang sedap. Bumbunya juga enak. Hanya saja kuah steaknya saya rasa sedikit. Dan lama juga nunggu pesanan saya datang.

Berdasarkan wawancara tersebut, maka dapat disimpulkan bahwa untuk menambah kepercayaan konsumen, Waroeng Steak and Shake telah mendaftarkan produknya di LPPOM MUI dan telah mendapatkan sertifikat halal. Allah memerintahkan kita untuk memakan makanan yang bukan cuma halal, tapi juga baik (halalan thoyyiban) agar tidak membahayakan tubuh kita. Bahkan perintah ini disejajarkan dengan bertaqwa kepada Allah, sebagai sebuah perintah yang sangat tegas dan jelas. Perintah ini juga ditegaskan dalam ayat yang lain, seperti yang terdapat pada Surat Al Baqarah : 168 yang artinya: 
Rizka Ar Rahmah: Penerapan Etika Bisnis Islam Pada Waroeng Steak |255

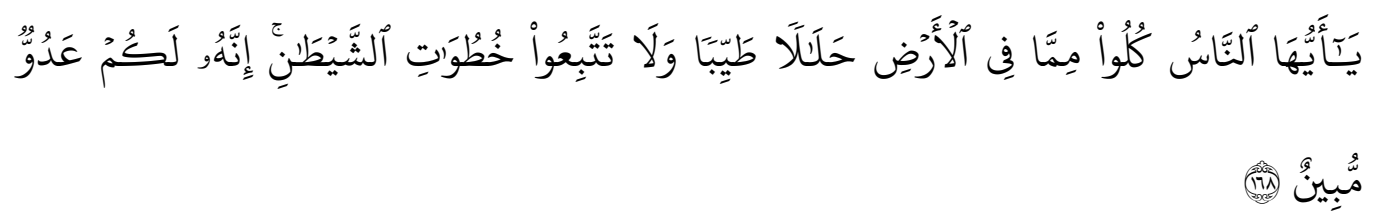

Artinya: Hai sekalian manusia, makanlah yang halal lagi baik dari apa yang terdapat di bumi, dan janganlah kamu mengikuti langkah-langkah syaitan; karena sesungguhnya syaitan itu adalah musuh yang nyata bagimu.

Dengan telah terdaftarnya produk Waroeng Steak and Shake di LPOM MUI dan lulus mendapatkan sertifikat Halal maka konsumen akan lebih tenang untuk membeli di Waroeng Steak and Shake. Dengan begitu Warong Steak and Shake telah jujur dalam menjual produknya kepada konsumen bahwa bahan yang mereka gunakan benar baik dan halal.

b) Jujur dalam bertransaksi

Menerapkan sifat jujur dalam berbisnis merupakan hal yang sangat penting. Karena Allah memerintahkan hambaNya untuk selalu memiliki sifat jujur, juga dengan adanya sifat jujur ini akan mendatangkan keberkahan dalam bisnis. Waroeng Steak and Shake berusaha unuk selalu mengajarkan karyawannya bersikap jujur dalam menjalankan tugasnya. Dan hal itu tampak dalam hasil wawancara penulis dengan Delvi, salah satu konsumen Waroeng Steak and Shake ${ }^{20}$ :

Saya suka ngumpul dengan teman-teman itu di Waroeng Steak and Shake ini karena saya pernah punya pengalaman baik disini. Pernah saya mesan jus, ternyata ketika baru sedikit saya minum lalat masuk kedalam gelasnya. Saya langsung memanggil karyawan untuk kembali memesan minuman yang sama. Pada saat membayar ternyata minum yang saya bayar itu hanya satu. Minuman kedua yang saya pesan tidak masuk kedalam hitungan. Setelah saya konfirmasi ke kasir ternyata mereka mengganti minum saya yang dimasuki lalat tersebut. Jadi saya menilai mereka berbisnis dengan jujur.

Jujur dalam bertransaksi juga berarti pihak manajemen Waroeng Steak and Shake tidak menjual steak dari daging yang tidak layak dijadikan steak. Dalam hal ini tidak layaknya bukan karena dagingnya tidak bagus tetapi misalnya dalam hal salah potong ukuran. Suwanda, salah satu karyawan di $\operatorname{sini}^{21}$ menjelaskan bahwa: 
Disini, daging yang salah potong tidak akan kami gunakan untuk membuat steak. Tetapi tidak akan kami buang juga. Nah, daging yang salah potong tersebut kami sebut tetelan. Disini, tetelan itu dijual kembali dengan harga yang murah. Banyak karyawan yang biasa beli untuk dimasak sendiri. Akan tetapi untuk tetelan itu kan enggak setiap hari ada. Hanya ketika ada daging yang salah potong saja sehingga enggak mungkin dimasak untuk konsumen.

Allah telah berfirman dalam QS. At Taubah: 119

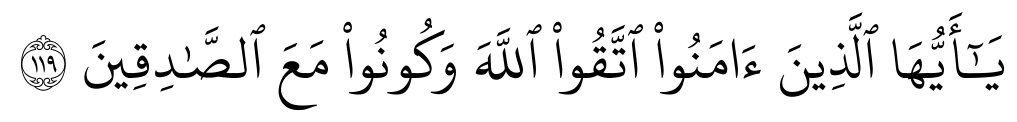

Artinya: Hai orang-orang yang beriman bertakwalah kepada Allah, dan hendaklah kamu bersama orang-orang yang benar.

Dengan adanya sifat jujur pada semua pelaku bisnis maka usaha bisnis akan berjalan baik, serta tidak ada pihak yang dirugikan. Dengan adanya sifat jujur dan berterus terang tanpa ada pihak yang dibohongi akan menimbulkan keadilan bagi semua pihak. Dalam transaksi yang terjadi antara penjual dan pembeli bila keduanya sama-sama berlaku jujur dan terus terang, akan diberkahi bagi keduanya keberkahan.

\section{2) Amanah}

Sikap bertanggung jawab dan dapat dipercaya yang ditampilkan Waroeng Steak and Shake Cabang SM Raja Medan meliputi hal-hal berikut:

a) Akuntabilitas

Berdasarkan hasil wawancara dengan D, salah satu karyawan di sini ${ }^{22}$ :

Waroeng Steak and Shake setiap harinya membuat laporan keuangan pemasukan dan pengeluaran outlet. Semua itu akan dilaporkan setiap harinya ke ketua keuangan. Lalu diteruskan melalui email ke pusat di Yogyakarta.

Dari hasil wawancara tersebut dapat diketahui bahwa Waroeng Steak and Shake Cabang SM Raja Medan memiliki catatan atas transaksi keuangannya. Hal ini dimaksudkan untuk mengetahui berapa jumlah keuntungan maupun kerugian yang diterimanya dalam jangka waktu tertentu. Akuntansi merupakan salah satu bentuk pertanggungjawaban kepada penanggungjawab keuangan. Akuntabilitas sebagai 
perwujudan sifat amanah dari kepala bagian keuangan kepada pemilik Waroeng Steak and Shake. laporan pertanggungjawaban ini pun menjadi tolok ukur bagi Waroeng Steak and Shake Cabang SM Raja Medan, mengalami kemajuan ataukah kemunduran. Sehingga sangat penting sifat ini diterapkan dan diaplikasikan dalam suatu bisnis.

b) Tanggungjawab sosial

Sikap bertanggungjawab yang dimiliki oleh Waroeng Steak and Steak diantaranya adalah tanggungjawab sosial. Beberapa kegiatan sosial yang telah dilaksanakan oleh Waroeng Steak and Shake antara lain:

$\checkmark$ Penyaluran Dana Bantuan

Setiap setengah tahun sekali pihak Waroeng Steak and Shake mengadakan penyaluran bantuan untuk daerah yang kurang mampu. Bantuan bisa saja disalurkan melalui sekolah atau langsung ke masyarakatnya. Dalam kesempatan ini penulis berkesempatan untuk mengikuti kegiatan penyaluran dana bantuan ke Sekolah Yayasan Perguruan Nurul Iman Karya Maju di daerah Tanjung Pura, Langkat. Kegiatan diadakan pada tanggal 1 Juni 2016.

$\checkmark$ Berbagi Parcel lebaran untuk para dhuafa. ${ }^{23}$

Manajemen Waroeng Steak and Shake banyak melakukan kegiatan sosial untuk membantu masyarakat yang masih membutuhkan salah satunya adalah kegiatan berbagi parcel untuk para dhuafa. Kegiatan yang dilakukan sejalan dengan atribut yang banyak ditempelkan di dinding outlet bertuliskan bahagia itu saat kita berbagi. Seperti penuturan $\mathrm{T}$, petugas parkir di $\operatorname{sini}^{24}$ :

Saya senang kerja disini, karena manajemennya bagus, suka merhatikan orang yang kurang mampu. Suka berbagi misalnya lebaran tahun lalu, saya termasuk orang yang dapat parcel lebaran. Selebihnya setau saya masyarakat disekitar outlet disini juga banyak yang dapat. Alhamdulillah semoga berkah terus bisnisnya.

$\checkmark$ Kegiatan Bantuan Untuk Korban Bencana Alam ${ }^{25}$

Di outlet Waroeng Steak and Shake disediakan kotak sedekah. Dimana kotak sedekah ini adalah alokasi sekian persen dari pembayaran para pelanggan untuk 
dialokasikan sedekah agar kita juga bisa berbagi ke sesama. Selain itu tiap tanggal 27 April serentak di semua Waroeng Steak and Shake di seluruh Indonesia omset penjualan hari itu $100 \%$ akan disedekahkan bagi siapa saja yang berhak menerimanya.

c) Memberikan Pelayanan yang Optimal

Waroeng Steak and Shake Cabang SM Raja Medan berusaha memberikan pelayanan terbaik kepada konsumen, artinya bahwa konsumen sebagai raja dan konsumen diprioritaskan dalam terciptanya kebutuhan mereka. Yaitu dengan cara memberikan pelayanan yang tepat dan cepat, murah senyum, serta pelayanan ramah. Rasulullah sangat menganjurkan para pelaku bisnis untuk bermurah hati dalam setiap transaksi, murah senyum dan ramah tamah.

Herlinayanti Harahap ${ }^{26}$ salah seorang pelanggan Waroeng Steak \& Shake Cabang SM Raja Medan mengatakan:

Pelayanan yang diberikan kurang memuaskan, lambat dan kurang care terhadap pelanggan. Mungkin lambat karena saya datang disaat jam makan siang jadi ramai, ya walaupun begitu setidaknya kalau saja karyawannya lebih care dengan pelanggan perasaan kurang memuaskan karena pesanan datang lama lebih terobati.

Sedangkan A, karyawan bagian depan Waroeng Steak and Shake mengatakan dalam wawancara ${ }^{27}$ :

Kami sudah berusaha semaksimal mungkin untuk memberikan pelayanan yang optimal kepada konsumen. Baik itu dalam hal ketepatan pengantaran, maupun ramah tamah. Namun terkadang, ketika outlet sedang ramai sesekali masih terjadi komplain dari konsumen karena menu yang mereka pesan lama diantar. Kami sudah mengantisipasi dengan menambah staf memasak di dapur. Alhamdulillah komplain seperti mulai jarang terjadi lagi.

Dalam setiap usaha bisnis yang dilakukan, pelayanan terhadap konsumen merupakan hal yang sangat membutuhkan perhatian khusus karena salah satu faktor yang bisa mempertahankan keberlangsungan usaha adalah kepuasan konsumen terhadap pelayanan yang diberikan. Akhlak tolak ukurnya dengan menggunakan Al- 
Rizka Ar Rahmah: Penerapan Etika Bisnis Islam Pada Waroeng Steak |259

Qur'an dan Sunnah. Jadi, segala tindakan yang dilakukan oleh semua jajaran manajemen haruslah sesuai dengan tuntunan Al-Qur'an dan Sunnah.

Kesimpulannya adalah pelayanan yang diberikan kepada konsumen masih membutuhkan perhatian khusus oleh manajemen Waroeng Steak and Shake. Dengan memperbaiki pelayanan yang diberikan diharapkan akan meningkatkan kepuasan konsumen.

d) Menepati Janji

Sesuai dengan dasar perusahaan yaitu Spritual Company, Waroeng Steak and Shake konsisten memberangkatkan karyawan umroh di setiap tahunnya. Maksud dari Spiritual Company disini adalah segala hal yang dilakukan perusahaan sesuai dengan ajaran agama Islam di keseharian para karyawan. Terdapat 20 karyawan yang di berangkatkan umroh pada tahun ini. Program ini merupakan sumbangsih perusahaan serta bentuk motivasi kepada karyawan agar tidak hanya masalah duniawi saja yang dikejar melainkan harus seimbang antara dunia dan akhirat.

Yusuf, supervisor outlet Waroeng Steak and Shake dalam hasil wawancara mengatakan $^{28}$ :

Pemilik Waroeng Steak and Shake selalu rutin mengumrohkan karyawan yang memang terpilih untuk diberikan umroh gratis. Jadi kupon itu sangat berguna bagi karyawan. Setiap karyawan berlomba untuk mendapatkan kupon tersebut dengan rajin menyetor 4 Surah yang sudah dipilih. Selanjutnya kupon tersebut dikumpulkan untuk kemudian diundi siapa pemenang umroh setiap tahunnya.

Seluruh karyawan Waroeng Steak and Shake memiliki kesempatan yang sama untuk memenangkan undian berhadiah umroh ini. Tentunya, terdapat persyaratan yang harus dipenuhi oleh setiap karyawan. Persyaratannya adalah karyawan cukup menghafal beberapa surat Al-Quran yaitu surat Yasin, Al Mulk, Al Waqiah dan Ar Rahman. Karyawan yang hafal satu surat berhak atas 1 kupon undian umroh, begitupun jika ada yang sampai hafal empat surat berarti mendapatkan 4 kupon undian umroh. Undian umroh tersebut diundi pada saat acara syawalan (halal bihalal) keluarga besar Waroeng Steak and Shake. Diharapkan dengan program ini karyawan menjadi lebih termotivasi untuk lebih dekat dengan Al Quran 
260 |AT-TAWASSUTH: Jurnal Ekonomi Islam, Volume V No. 2

Juli - Desember 2020: 246 - 267

\section{3) Tabligh}

Komunikatif dan argumentatif yang ditampilkan oleh Waroeng Steak and Shake Cabang SM Raja Medan meliputi hal-hal berikut:

a) Komunikasi Bisnis

Dari hasil observasi peneliti dapat menyimpulkan bahwa dalam berkomunikasi dengan konsumen Waroeng Steak and Shake Cabang SM Raja Medan sudah menggunakan bahasa yang sopan dan halus. Namun ada beberapa hal yang menjadi kelemahan dalam segi komunikasi ini. Seperti penuturan Wika, salah satu pelanggan di $\operatorname{sini}^{29}$ :

Sebenarnya bahasa yang digunakan sudah baik, hanya saja akan lebih baik jika dari datang dan selesai konsumen itu di sambut. Misalnya, dengan mengucapkan terimakasih ketika kita hendak meninggalkan outlet.

Sejalan dengan itu menurut Yani, salah satu pelanggan di sini memberikan jawaban dalam wawancara ${ }^{30}$ :

Kalau saya menilainya pelayanan disini masih biasa saja. Misalnya, saat memberi menu, hanya memberikan draft menu lalu hanya bilang, mau pesan apa kak? Kalau misalnya dijelaskan tentu akan lebih baik. Misalnya ini menunya mbak, mbak mau pesan apa ya? Menu favorit di sini ini dan ini mbak, jadi bisa rekomendasi menu ini untuk dipesan. Minuman yang paling recomended yang ini mbak. Nah, begitu kan enak.

Kesimpulan yang dapat diambil adalah, komunikasi bisnis Waroeng Steak and Shake masih harus diperbaiki lagi. Karena dengan menjalin hubungan komunikasi yang baik dan interaksi yang menyenangkan dengan pelanggan dapat membentuk reputasi perusahaan yang baik. Dengan begitu, pelanggan dapat menilai kualitas dan kredibilitas perusahaan dalam melayani pelanggan. Bahkan profesionalitas layanan dari perusahaan akan dinilai positif di mata konsumen sehingga pelanggan akan bertambah dan menjadi customer yang setia.

b) Dakwah 
Rizka Ar Rahmah: Penerapan Etika Bisnis Islam Pada Waroeng Steak |261

Dakwah bisa dilakukan melalui apa saja, termasuk melalui kegiatan bisnis. Beberapa dakwah yang dilakukan oleh manajemen Waroeng Steak and Shake Cabang SM Raja Medan diantaranya adalah:

$\checkmark$ Simbol-Simbol

Waroeng Steak and Shake banyak melekatkan label Islam dalam menjalankan bisnisnya. Misalnya, dengan melekatkan gambar-gambar yang sarat dengan nilai keislaman, contoh gambar yang bertuliskan makanlah dengan tangan kanan. Dalam hal ini karena Steak yang berasal dari negara Barat biasanya dikonsumsi dengan cara memegang garpu ditangan kiri dan pisau untuk memotong steak di tangan kanan. Sehingga otomatis tangan kiri yang memegang garpulah yang akan digunakan untuk makan. Akan tetapi hal tersebut tidaklah sesuai dengan ajaran Islam yang mengharuskan makan dengan tangan kanan. Sehingga melalui media yang dilekatkan di dinding outlet yang bertuliskan makanlah dengan tangan kanan, pihak manajemen berusaha untuk mengingatkan konsumen agara tetap makan sesuai dengan ketentuan Islam. Menurut Yusuf, Supervisor Outlet, Waroeng Steak and Shake dalam wawancara $^{31}$ :

Kami berusaha menyampaikan dakwah Islam dengan cara seperti ini. Ya, mengingatkan kalau makan mulailah dengan dengan membaca do'a, makanlah dengan tangan kanan, dan juga berbagi itu indah. Dengan begitu konsumen akan terbiasa untuk melaksanakan hal-hal yang baik tersebut.

$\checkmark$ Mengumandangkan adzan setiap waktu shalat tiba

Contoh lainnya adalah adanya adzan di setiap waktu shalat sehingga mengingatkan konsumen bahwa waktu shalat telat tiba dan bergegas untuk segera melaksanakan shalat. Selain untuk mengingatkan konsumen, jika waktu adzan telah tiba maka para karyawan juga akan bergantian untuk melaksanakan shalat.

$\checkmark$ Menyediakan mushalla, Al-Qur'an, sajadah, sarung dan mukena

Pihak manajemen juga menyediakan mushalla untuk melaksanakan ibadah shalat bagi karyawan outlet pengunjung yang beragama Islam. Tak lupa pihak manajemen menyediakan mukenah bagi pengunjung perempuan yang hendak shalat. Tak lupa juga menyediakan sajadah, sarung serta Al-Qur'an. Seperti penuturan Gusti $^{32}$ bahwa: 
262 AT-TAWASSUTH: Jurnal Ekonomi Islam, Volume V No. 2

Juli - Desember 2020: 246 - 267

Di dalam mushallah, selain menyediakan perlengkapan shalat seperti sajadah, sarung dan mukenah. Kami juga menyediakan beberapa buku bacaan tentang hadis. Jadi untuk nambah ilmu tentang hadis siapa saja bisa baca di mushallah. Mushallah juga kami jaga kebersihannya supaya siapapun yang beribadah bisa nyaman ibadahnya.

Fungsi tempat ibadah adalah agar memudahkan konsumen untuk melaksanakan ibadahnya. Maka diharapkan dengan adanya sarana ibadah yang telah disediakan oleh pihak manajemen maka akan memberikan manfaat kepada konsumen agar konsumen menjadi lebih beriman dan berakhlak baik.

$\checkmark$ Mengadakan hari bebas rokok nasional

Setiap tanggal 31 Mei, manajemen Waroeng Steak and Shake mengadakan hari Bebas asap rokok diseluruh outlet ${ }^{33}$ Waroeng Group kembali menggelar Hari Bebas Asap Rokok untuk mengampanyekan hari tanpa tembakau sedunia yang diperingati setiap tanggal 31 Mei. Hari tanpa tembakau sedunia merupakan hari untuk menarik perhatian dunia mengenai buruknya kebiasaan merokok dan dampak negatif yang bisa ditimbulkan dari merokok.Oleh karena itu, Waroeng Group membuat program Hari Bebas Asap Rokok diseluruh outletnya.

\section{4) Fathanah (Kecerdasan)}

Kecerdasan yang ditunjukkan oleh Waroeng Steak and Shake Cabang SM Raja Medan meliputi hal-hal berikut:

a) Kecerdasan spiritual

Kecerdasan spiritual yang dilakukan yaitu dalam bentuk menjalankan sholat wajib,dan melaksanakan sholat sunnah dhuha. Beberapa hal yang mencakup penerapan ibadah di Waroeng Steak and Shake antara lain adalah pengerjaan shalat 5 waktu dan lebih baik lagi apabila ditambah dengan shalat sunnahnya. Di outlet Waroeng Steak and Shake Cabang SM Raja, pelaksanaan shalat fardhu oleh segenap karyawan terus dilakukan perbaikan. Beberapa usaha yang dilakukan pihak manajemen untuk memperbaiki ibadah wajib shalat fardhu diantaranya adalah dengan secara bergantian menugaskan karyawannya pada waktu subuh untuk piket membangunkan shalat subuh untuk teman-temannya. Seperti penuturan Yusuf ${ }^{34}$ : 
Rizka Ar Rahmah: Penerapan Etika Bisnis Islam Pada Waroeng Steak |263

Setiap outlet kami menugaskan satu orang untuk bertugas membangunkan shalat subuh setiap karyawan. Namun, tetap saja terkadang mereka bangun subuh kesiangan. Yang bertugas membangunkan dan karyawan lain samasama telat bangunnya. Terakhir, shalat subuhnya jadi telat. Hal inilah yang masih jadi tugas kami untuk terus memperbaikinya.

Padahal banyak keutamaan yang bisa didapat apabila seseorang mengerjakan shalat shubuh. Tidakkah kita takut dikatakan sebagai orang yang munafiq karena meninggalkan shalat shubuh? Dan kebanyakan orang meninggalkan shalat shubuh karena aktivitas tidur. Nabi Shallallahu 'Alaihi Wa Sallam bersabda:

Sesungguhnya shalat yang paling berat dilaksanakan oleh orang-orang munafik adalah shalat isya dan shalat subuh. Sekiranya mereka mengetahui keutamaan keduanya, niscaya mereka akan mendatanginya sekalipun dengan merangkak. ${ }^{35}$

Cukuplah ancaman dikatakan sebagai orang munafiq membuat kita selalu memperhatikan ibadah yang satu ini. Untuk shalat Isya selalu diadakan secara berjamaah setelah outlet tutup. Selain itu yang selalu dilaksanakan berjamaah adalah shalat sunnah dhuha sebelum outlet dibuka. Andre ${ }^{36}$, bahwa:

Setiap harinya disini kami melaksanakan shalat berjamaah untuk Isya dan shalat Dhuha karena pada saat itu outlet sudah tidak ada pelanggan lagi. Untuk Dhhuha dilakukan sebelum outlet buka sedangkan untuk Isya setelah outlet buka. Untuk shalat wajib lainnya masih dilakukan secara bergantian.

Menurut $S^{37}$ kegiatan shalat wajib shalat lima waktu ditambah dhuha yang diwajibkan oleh pihak manajemen memberikan dampak positif untuk dirinya:

Sebelum kerja di Waroeng Steak and Shake ini, saya itu jarang lakuin shalat. Suka bolong-bolong shalatnya mbak, tapi setelah bekerja disini alhamdulillah shalat saya udah full. Walaupun awalnya saya ngelakuin karena disini itu adalah juga kewajiban trus kalau tidak akan mendapat nilai tidak baik di rapor, tetapi lama kelamaan saya mulai sadar kalau semenjak saya shalat dengan niat memang untuk beribadah kepada Allah, memang kewajiban 
sebagai seorang Muslim, Allah memberikan ketenangan dalam diri saya. Saya juga ngerasa perlahan saya mulai lebih baik dalam bertindak.

Dalam Surat Al-Ankabut ayat 45,

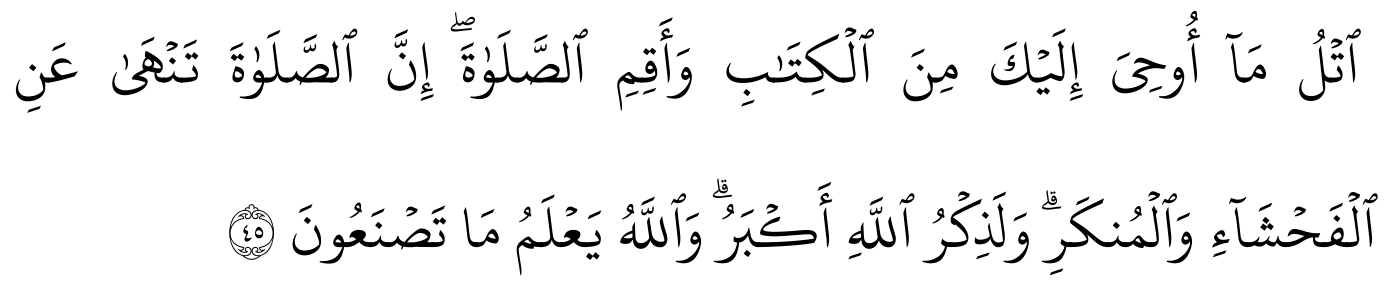

Artinya: Bacalah apa yang telah diwahyukan kepadamu, yaitu Al Kitab (Al Quran) dan dirikanlah shalat. Sesungguhnya shalat itu mencegah dari (perbuatanperbuatan) keji dan mungkar. Dan sesungguhnya mengingat Allah (shalat) adalah lebih besar (keutamaannya dari ibadat-ibadat yang lain). Dan Allah mengetahui apa yang kamu kerjakan.

\section{Kesimpulan}

Pelaksanaan ibadah shalat wajib dan sunnah oleh seluruh karyawan outlet sudah berjalan baik namun perlu adanya program tambahan untuk lebih menguatkan ibadah wajib tersebut. Jadi program baru yang ditawarkan adalah Shalat Berjamaah Dzuhur, Ashar dan Maghrib secara bergantian. Program ini diharapkan akan memberi warna yang lebih untuk karyawan outlet untuk terbiasa mengutamakan kewajiban kepada Allah agar mendapat berkah. Jadi, bekerja sambil beribadah.

Pebisnis Muslim harusnya mampu mencontoh kecerdasan spiritual yang dimiliki oleh Rasulullah. Spiritualisasi ala Nabi Muhammad yaitu mengawali bisnis dengan basmallah dan mengakhiri dengan hamdallah, bersedekah, mengerjakan sholat wajib tepat waktu, melaksanakan sholat sunnah, mengerjakan puasa sunnah dan selalu berdoa kepada Allah. Dengan demikian dapat disimpulkan bahwa seluruh staf Waroeng Steak and Shake Cabang SM Raja Medan telah memiliki kecerdasan spiritual meskipun tidak sesempurna Rasulullah. Dengan kecerdasan spiritual yang dimiliki, maka staf Waroeng Steak and Shake Cabang SM Raja Medan akan merasakan ketenangan hati dan setiap tingkah lakunya akan terjaga dari hal-hal yang menyimpang dari ajaran Islam. 
Berkaitan dengan sifat mulia dan terpuji nabi Muhammad, sifat-sifat terebut dapt diterapkan dalam kehidupan berbisnis atau bermuamalah di jaman sekarang. Karena dilihat dari manapun semua etika bisnis ataupun aturan bermula dan berakar dari 4 hal yang menjadi merupakan sifat terpuji Nabi Muhammad, yang seharusnya diterapkan tanpa banyak pertimbangan dan modifikasi sehingga menjadi semakin rumit. Sifat-sifat itu berlaku universal, selalu relevan dengan tuntutan dan kebutuhan zaman. Kapan pun manusia membutuhkan orang yang memiliki sifat-sifat mulia itu.

Endnote

${ }^{1}$ Yusuf Qardhawi. Norma dan Etika Ekonomi Islam. (Jakarta: Gema Manusia Press, 1993) h.5

${ }^{2}$ Muslich. Etika Bisnis Islam. (Jakarta: Ekonisia, 2004) Cet. I . h. 29

${ }^{3}$ Muhammad, Faurori R. Lukman, Visi Alquran Tentang Etika dan Bisnis, (Jakarta: Diniyah, 2002), h. 1

${ }^{4}$ O.P. Simorangkir, Etika Bisnis, Jabatan dan Perbankan, Jakarta: PT. Rineka Cipta, 2003, h. 3.

${ }^{5}$ Suparman Syukur, Etika Religius, (Yogyakarta : Pustaka Pelajar, 2004), h. 1.

${ }^{6}$ Abdul Aziz, Etika Bisnis..., h, 28.

${ }^{7}$ Ibid., h, 28.

${ }^{8}$ Ibid., h, 29.

${ }^{9}$ Faisal Badroen dkk, Etika Bisnis dalam Islam, cet IV (Jakarta : Prenadamedia Group, 2015), h, $19-20$

${ }^{10}$ Windya Novita, Mendulang Rizki dengan Bisnis Syar'i (Jakarta: PT Gramedia), h.137.

${ }^{11}$ (QS. An-Najm : 4.

${ }^{12}$ Q.S An-Najm / 53:4

${ }^{13}$ Q.S Al-A'raf /7:68

${ }^{14}$ Q.S Al-Jin/ 72:28 Karya) h.5

${ }^{15}$ Moleong, Lexy, 2001, Metodologi Penelitian Kualitatif, (Bandung: PT. Remaja Rosada

${ }^{16}$ Muhamad Nazir, 1983, Metode Penelitian, (Jakarta:Ghalia Indonesia). h.105

${ }^{17}$ Yusuf, Supervisor Outlet, Waroeng Steak and Shake, wawancara dilaksanakan di Medan, 8 Januari 2020 Januari 2020

${ }^{18}$ E, bagian dapur pusat Waroeng Steak and Shake, wawancara dilakukan di Medan 14 2020

${ }^{19}$ Putri, pelanggan Waroeng Steak and Shake, wawancara dilakukan di medan 25 Januari

${ }^{20}$ Delvi, pelanggan Waroeng Steak and Shake, wawancara dilakukan di medan 25 Januari 2020

${ }^{21}$ Suwanda, karyawan bagian dapur, wawancara dilakukan di Medan 22 Januari 2020

${ }^{22}$ D, karyawan bagian keuangan Waroeng Steak and Shake, wawancara dilakukan di Medan 14 Januari 2020

Sumber: website Waroeng Steak and Shake, http://www.waroengsteakandshake.com/news/297/berbagi-parcel-lebaran-untuk-para-dhuafa, diakses 4 Januari 2020 jam 15:05

${ }_{25}^{24} \mathrm{~T}$, petugas parkir Waroeng Steak and Shake.

25 Sumber: website http://www.waroengsteakandshake.com/news/194/waroeng-pedulibersama-pkpu-salurkan-bantuan-bagi-korban-banjir-bandang-di-sumatera diakses tanggal 4 Juli 2020 jam 15:10 
266 |AT-TAWASSUTH: Jurnal Ekonomi Islam, Volume V No. 2

Juli - Desember 2020: 246 - 267

26 Herlinayanti Harahap, pelanggan Waroeng Steak and Shake, wawancara dilakukan di Medan tanggal 15 Januari 2020

27 A, karyawan bagian depan Waroeng Steak and Shake, wawacara dilakukan di Medan tanggal 15 Januari 2020.

${ }^{28}$ Yusuf, supervisor outlet Waroeng Steak and Shake

${ }^{29}$ Wika, pelanggan

${ }^{30}$ Yani, pelanggan

${ }^{31}$ Yusuf, Supervisor Outlet, Waroeng Steak and Shake

${ }^{32}$ Gusti, ketua bagian depan

${ }^{33}$ Sumber: website Waroeng Steak and Shake, http://www.waroengsteakandshake.com/news/286/31-mei-bebas-asap-rokok-diseluruh-outlet

${ }^{34}$ Yusuf, Supervisor Outlet, Waroeng Steak and Shake

${ }^{35}$ HR. Bukhari no. 657 dan Muslim no. 651

${ }^{36}$ Andre, karyawan bagian depan

${ }^{37} \mathrm{~S}$ adalah karyawan bagian depan, wawancara

\section{Daftar Pustaka}

Badroen, Faisal, et.al. 2015. Etika Bisnis dalam Islam, Cet. IV Jakarta: Prenadamedia Group

Famiola, et. al, 2008. SocialMapping, Bandung : PT. Rekayasa Sains.

Lexy, Moleong. 2001. Metodologi Penelitian Kualitatif, PT. Remaja Rosada Karya: Bandung.

Lukman, Muhammad Faurori R. 2002. Visi Alquran Tentang Etika dan Bisnis, Jakarta: Diniyah.

Muslich. 2004. Etika Bisnis Islam.Cet I Jakarta: Ekonisia.

Nazir, Muhamad. 1983. Metode Penelitian, Jakarta: Ghalia Indonesia.

Novita, W. (2013). Mendulang Rezeki Dengan Bisnis Syar'i. Gramedia Pustaka Utama.

Simorangkir, O.P. 2003. Etika Bisnis, Jabatan dan Perbankan, Jakarta: PT. Rineka Cipta.

Syukur, Suparman. 2004. Etika Religius, Yogyakarta : Pustaka Pelajar.

Waroeng Steak and Shake,

http://www.waroengsteakandshake.com/news/297/berbagi-parcel-lebaranuntuk-para-dhuafa 
Rizka Ar Rahmah: Penerapan Etika Bisnis Islam Pada Waroeng Steak |267

http://www.waroengsteakandshake.com/news/194/waroeng-peduli-bersama-pkpusalurkan-bantuan-bagi-korban-banjir-bandang-di-sumatera 